\title{
Pengaruh Partisipasi Anggaran Terhadap Kinerja Manajerial Dengan Self Efficacy Sebagai Variabel Intervening
}

\author{
Septi Yuniarti \\ Manajemen, Fakultas Ekonomi Universitas PGRI Palembang, septiyuniarti@gmail.com
}

\begin{abstract}
ABSTRAK
Partisipasi dalam penyusunan anggaran merupakan tingkat seberapa besar keterlibatan dan pengaruh manajer dalam proses penyusunan anggaran suatu departemen atau bagiannya baik secara periodik maupun tahunan. Adapun tujuan dari penelitian ini adalah untuk melihat pengaruh dari partisipasi anggaran terhadap kinerja manajerial dengan self efficacy sebagai variabel intervening. Metode yang digunakan dalam penelitian ini adalah survey lapangan (field research) yang dilakukan dengan mengambil sampel dari suatu populasi yakni perusahaan manufaktur skala menengah dan perusahaan besar di wilayah Kota Palembang. Data kemudian dianalisis mengunakan Uji Validitas, Uji Reliabilitas dan Analisis Jalur. Hasil olah data dalam penelitian ini menunjukkan bahwa nilai hitung tabel thitung $>$ tabel $(2,284>1,652)$, dan probabilitasnya di bawah 0,05 , sehingga hipotesis pertama diterima karena memenuhi syarat yang telah ditentukan atau dapat diartikan terdapat pengaruh yang signifikan dari variabel partisipasi anggaran terhadap self efficacy. Hasil olah data dalam penelitian ini menunjukkan bahwa hitung tabel thitung $>t_{\text {tabel }}(2,284>1,652)$ dan nilai probabilitasnya berada di bawah 0,05 . Hal ini berarti terdapat pengaruh yang positif dan signifikan antara variabel self efficacy dengan kinerja manajerial.
\end{abstract}

Kata Kunci : Partisipasi Anggaran, Kinerja Manajerial, Self Efficacy

\section{A. PENDAhUluan}

Pada era sekarang ini, hanya perusahaan yang mampu melakukan efisiensi, peningkatan mutu dan peningkatan kinerja perusahaan yang mampu mempertahankan kelangsungan hidup perusahaan dan mampu untuk maju dan terus berkembang. Kondisi tersebut menuntut para pelaku bisnis untuk meningkatkan kinerja yang tidak lepas dari kemampuan dalam perencanaan, pengkoordinasian dan pengendalian berbagai aktivitas dan sumber daya yang dimiliki.

Pada umumnya perusahaan baik berskala besar maupun kecil menggunakan anggaran sebagai salah satu langkah awal dalam melaksanakan aktivitas bisnis. Anggaran adalah alat perencanaan dan pengendalian yang sangat penting dalam perusahaan, sehingga proses penyusunan anggaran merupakan aspek penting dalam pencapaian keberhasilan suatu organisasi. Anggaran tidak saja sebagai alat perencanaan keuangan dan pengendalian, tetapi juga sebagai alat koordinasi, komunikasi, evaluasi kinerja dan motivasi. Pengendalian dalam anggaran mencakup pengarahan dan pengaturan orangorang dalam organisasi. Proses penyusunan anggaran merupakan proses penetapan peran, dimana pihak-pihak yang berkaitan diberi peran untuk melaksanakan kegiatan pencapaian sasaran yang ditetapkan dalam anggaran.

Anggaran merupakan komponen penting dalam sebuah organisasi, baik organisasi sektor swasta maupun organisasi sektor publik. Setiap entitas pencari laba ataupun nirlaba bisa mendapatkan manfaat dari perencanaan dan pengendalian yang diberikan oleh anggaran. Perencanaan dan pengendalian merupakan dua hal yang saling berhubungan. 
Perencanaan adalah pandangan ke depan untuk melihat tindakan apa yang seharusnya dilakukan agar dapat mewujudkan tujuan-tujuan tertentu. Pengendalian adalah melihat ke belakang, memutuskan apakah yang sebenarnya telah terjadi dan membandingkannya dengan hasil yang direncanakan sebelumnya.

Penyusunan

anggaran merupakan suatu proses yang berbeda antara sektor swasta dengan sektor pemerintah, termasuk diantaranya pemerintah daerah. Pada sektor swasta, anggaran merupakan bagian dari rahasia perusahaan yang tertutup untuk publik, namun sebaliknya pada sektor pemerintahan atau publik anggaran justru harus diinformasikan kepada publik untuk dikritik dan didiskusikan dengan tujuan untuk mendapatkan masukan. Anggaran sektor publik merupakan instrument akuntabilitas atas pengelolaan dana public dan pelaksanaan programprogram yang dibiayaai dari uang public (Mardiasmo, 2009). Anggaran digunakan sebagai pedoman kerja sehingga proses penyusunannya memerlukan organisasi anggaran yang baik, pendekatan yang tepat, serta model-model perhitungan besaran (simulasi) anggaran yang mampu meningkatkan kinerja pada seluruh jajaran manajemen dalam organisasi. Proses penyusunan anggaran dapat dilakukan dengan beberapa pendekatan yaitu topdown, bottom up dan partisipasi (Ramadhani dan Nasution, 2009).

Dalam perusahaan, kinerja manajerial dihubungkan dengan partisipasinya dalam penyusunan anggaran. Partisipasi dalam penyusunan anggaran merupakan tingkat seberapa besar keterlibatan dan pengaruh manajer dalam proses penyusunan anggaran suatu departemen atau bagiannya baik secara periodik maupun tahunan.

Self efficacy adalah kemampuan yang diyakini seseorang untuk melaksanakan tugas dan perilaku ini telah terbukti menjadi determinan perilaku proaktif, misalnya inovasi karyawan. Self efficacy sebagai sebuah variabel yang mempengaruhi perilaku pencapaian prestasi, keputusan akademik dan karir, serta penyesuaian karir. Individu dengan self efficacy tinggi lebih bersemangat dan tidak kenal menyerah dalam usahausahanya dalam mencapai tujuan, meskipun berhadapan dengan berbagai hambatan dan pengalaman kegagalan, sedangkan individu dengan self efficacy yang rendah cenderung berdiam diri dan menyerah apabila berhadapan dengan hambatanhambatan.

Penelitian ini bertujuan untuk mengetahui sejauh mana pengaruh partisipasi penyusunan anggaran terhadap kinerja manajerial yang diterapkan pada perusahaan manufaktur di wilayah Kota Palembang dengan menggunakan self efficacy sebagai variabel intervening.

\section{B. KAJIAN TEORI}

\section{1) Partisipasi Anggaran \\ Partisipasi dalam proses} penyusunan anggaran dianggap oleh sebagian orang sebagai obat mujarab untuk memenuhi kebutuhan akan harga diri dan aktualisasi dari para anggota organisasi. Dengan kata lain, pekerja dan manajer tingkat bawah memiliki suara dalam proses manajemen. Partisipasi secara luas pada dasarnya merupakan proses organisasional, dimana para individual terlibat dan mempunyai pengaruh dalam pembuatan keputusan yang mempunyai pengaruh secara langsung terhadap para individu tersebut. 
Partisipasi adalah suatu "proses pengambilan keputusan bersama oleh dua bagian atau lebih pihak dimana keputusan tersebut akan memiliki dampak masa depan terhadap mereka yang membuatnya". Arfan dan Muhammad (2008).

Menurut Eka Yuda (2013) partisipasi merupakan proses dimana individu-individu terlibat langsung didalamnya dan mempunyai pengaruh pada penyusunan target anggaran yang kinerjanya akan dievaluasi dan kemungkinan akan dihargai atas dasar pencapaian target anggaran mereka. Jadi, partisipasi penyusunan anggaran adalah keterlibatan pihak-pihak secara langsung dalam proses pengambilan kebijakan penyusunan anggaran.

\section{2) Manfaat Penyusunan Anggaran \\ Partisipasi}

Manfaat dari partisipasi dalam penyusunan anggaran menurut Arfan Ikhsan dan Muhammad Ishak (2008) adalah :

a) Partisipan menjadi terlibat secara emosi dan bukan hanya secara tugas dalam pekerjaan mereka. Partisipasi dapat meningkatkan moral dan mendorong inisiatif yang lebih besar pada semua tingkatan manajemen.

b) Partisipasi juga berarti meningkatkan rasa kesatuan kelompok, yang pada gilirannya cenderung meningkatkan kerja sama antar anggota kelompok dalam penetapan tujuan. Tujuan organisasi yang dibantu penetapannya oleh orang-orang tersebut, kemudian akan dipandang sebagai tujuan yang selaras dengan tujuan pribadi mereka.

c) Partisipasi berarti juga berkaitan dengan penurunan tekanan dan kegelisahan yang berkaitan dengan anggaran. Hal ini disebabkan orang yang berpartisipasi dalam penetapan tujuan mengetahui bahwa tujuan tersebut wajar dan dapat dicapai.

d) Partisipasi juga dapat menurunkan ketidakadilan yang dipandang ada dalam alokasi sumber daya organisasi antara sub unit organisasi, serta reaksi negatif yang dihasilkan dari persepsi semacam itu. Manajer yang terlibat dalam penetapan tujuan akan memiliki pemahaman yang lebih baik mengenai penyebab sumber daya dialokasikan dengan cara demikian.

e) Melalui proses negoisasi dan banyak diskusi anggaran yang terjadi dalam rapat, manajer akan menyadari masalah dari rekanrekannya di unit organisasi lainnya dan memiliki pemahaman yang lebih baik atas saling ketergantungan antar departemen. Dengan demikian, banyak masalah potensial yang berkaitan dengan anggaran dapat dihindari.

\section{3) Pengukuran Partisipasi Penyusunan Anggaran}

Pengukuran partisipasi dalam penyusunan anggaran diukur berdasarkan instrument. Pengukuran bertujuan untuk menilai partisipasi manajer dalam berbagai keputusan yang diambil oleh perusahaan. Partisipasi manajer dapat dilihat dari beberapa aspek, yaitu :
a) Keterlibatan manajer dalam penyusunan anggaran.
b) Wewenang manajer dalam penyusunan anggaran dan berlakunya anggaran.
c) Keterlibatan manajer dalam pengawasan proses penyusunan anggaran.
d) Keterlibatan manajer dalam tujuan pelaksanaan anggaran pada bidang yang dipimpin.


Proses penyusunan anggaran akan menetapkan siapa yang akan berperan dalam melaksanakan sebagian kegiatan pencapaian sasaran anggaran dan ditetapkan pula sumber daya yang disediakan bagi pemegang peran tersebut untuk memungkinkan melaksanakan perannya. Peran tersebut menuntut manajer untuk bisa mengarahkan bawahan agar bekerja dengan maksiamal guna mencapai tujuan yang ditetapkan.

\section{4) Kinerja Manajerial}

Manajer adalah seseorang yang bekerja dengan dan melalui orang lain dengan mengoordinasikan kegiatankegiatan pekerjaan guna mencapai tujuan organisasi. Hal ini dapat berarti mengoordinasikan pekerjaan dari satu kelompok atau departemen, atau dapat berarti menyelia satu orang saja. Pengoordinasian tersebut dapat juga mencakup pengoordinasian kegiatankegiatan pekerjaan suatu tim yang terdiri atas orang-orang dari organisasi berbeda, seperti karyawan temporer atau karyawan yang bekerja di pemasok dari organisasi tersebut (Arfan Ikhsan Lubis, 2011).

Malayu (2017) mengemukakan bahwa manajer adalah sumber aktivitas dan mereka harus merencanakan, mengorganisasi, mengarahkan dan mengendalikan semua kegiatan agar tujuan tercapai. Manajer harus memberikan arah kepada perusahaan yang dipimpinnya.

Kinerja adalah gambaran pencapaian pelaksanaan suatu kegiatan/program/ kebijaksanaan dalam mewujudkan sasaran, tujuan, visi dan misi organisasi. Secara umum, kinerja merupakan prestasi yang dicapai oleh organisasi dalam periode tertentu (Indra Bastian, 2006).

Mardiasmo (2009) mengatakan bahwa kinerja manajerial adalah gambaran seorang manajer mengenai tingkat pencapaian pelaksanaan suatu kegiatan atau program, kebijakan dalam mewujudkan sasaran, tujuan, visi dan misi organisasi yang tertuang dalam strategic planning suatu organisasi. Sedangkan menurut Mahoney (1963) dalam Nurcahyani (2010), kinerja manajerial diartikan sebagai kinerja individu dalam kegiatan manajerial yang meliputi perencanaan, investigasi, koordinasi, supervisi, pengaturan staf, negoisasi dan representasi.

Jadi, kinerja manajerial dapat diartikan juga sebagai tingkat pencapaian manajer dalam melaksanakan dengan perencanaan, pengorganisasian, pengarahan dan pengendalian kegiatan untuk mencapai tujuan organisasi.

\section{5) Konsep Self Efficacy}

Bandura mendefinisikan self efficacy sebagai judgment seseorang atas kemampuannya untuk merencanakan dan melaksanakan tindakan yang mengarah pada pencapaian tujuan tertentu. Bandura menggunakan istilah self efficacy mengacu pada keyakinan (beliefs) tentang kemampuan seseorang untuk mengorganisasikan dan melaksanakan tindakan untuk pencapaian hasil. Dengan kata lain, self efficacy adalah keyakinan penilaian diri berkenaan dengan kompetensi sesorang untuk sukses dalam tugas-tugasnya. Menurut Bandura, keyakinan self efficacy merupakan faktor kunci sumber tindakan manusia (human agency), "apa yang orang pikirkan, percaya dan rasakan mempengaruhi bagaimana mereka bertindak".

Disamping itu, keyakinan efficacy juga mempengaruhi cara atas pilihan tindakan seseorang, seberapa banyak upaya yang mereka lakukan, seberapa lama mereka akan tekun dalam menghadapi rintangan dan kegagalan, 
seberapa kuat ketahanan mereka menghadapi kemalangan, seberapa jernih pikiran mereka merupakan rintangan diri atau bantuan diri, seberapa banyak tekanan dan kegundahan pengelaman mereka dalam meniru (copying) tuntunan lingkungan, dan seberapa tinggi tingkat pemenuhan yang mereka wujudkan.

Menurut teori kognitif sosial Bandura, keyakinan self efficacy mempengaruhi pilihan orang dalam membuat dan menjalankan tindakan yang mereka kejar. Individu cenderung berkonsentrasi dalam tugas-tugas yang mereka rasakan mampu dan percaya dapat menyelesaikannya serta menghindari tugas-tugas yang tidak dapat mereka kerjakan. Keyakinan efficacy juga membantu menentukan sejauh mana usaha yang akan dikerahkan orang dalam suatu aktivitas, seberapa lama mereka akan gigih ketika menghadapi rintangan, dan seberapa ulet mereka akan menghadapi situasi yang tidak cocok. Keyakinan efficacy juga mempengaruhi sejumlah stress dan pengalaman kecemasan individu seperti ketika mereka menyibukan diri dalam suatu aktifitas. Secara eksplisit, Bandura sebagaimana dikutip oleh Pajares, menghubungkan self efficacy dengan motivasi dan tindakan, tanpa memperhatikan apakah keyakinan itu benar secara objektif atau tidak.

Dengan demikian, perilaku dapat diprediksi melalui self efficacy yang dirasakan (keyakinan seseorang tentang kemampuannya), meskipun perilaku itu terkadang dapat berbeda dari kemampuan aktual karena pentingnya self efficacy yang dirasakan.

Keyakinan

seseorang dapat membantu menentukan hasil yang diharapkan, karena individu memiliki confident dalam mengantisipasi hasil yang sukses. Misalnya, pembelajar yang confident dalam mengantisipasi kemampuan menulis, memiliki nilai yang tinggi dalam tugas kepenulisan dan mengharapkan mutu tugas mereka memperoleh manfaat akademik.

Sebaliknya, pembelajar yang ragu-ragu atas kemampuan menulis berpretensi akan memperoleh nilai rendah sebelum mereka mantap mulai menulis. Perasaan efficacy yang kuat meningkatkan kecapakan seseorang dan kesejahteraan (well being) dalam cara yang tak terbayangkan. Individu yang confident, memandang tugastugas yang sulit sebagai tantangan untuk dikuasai daripada sebagai ancaman untuk dihindari. Mereka memiliki minat yang lebih kuat dan keasyikan yang mendalam pada kegiatan, menyusun tujuan yang menantang mereka, dan memeliharan komitmen yang kuat serta mempertinggi dan mendukung usahausaha mereka dalam menghadapi kegagalan. Mereka lebih cepat memulihkan confident setelah mengalami kegagalan atau kemunduran.

Self efficacy yang tinggi membantu membuat perasaan tenang dalam mendekati tugas dan kegiatan yang sulit. Sebaliknya, orang yang meragukan kemampuan dirinya, mereka bisa percaya bahwa sesuatu itu lebih sulit daripada yang sesungguhnya.

\section{METODE PENELITIAN}

Penelitian ini meruapakan survey lapangan (field research) yang dilakukan dengan mengambil sampel dari suatu populasi dalam lingkungan yang sebenarnya. Menurut Suparmoko dan Sofilda, Eleonora.(2015) survey adalah pengumpulan informasi tentang sekelompok manusia, dimana suatu hubungan langsung dengan obyek 
yang dipelajari seperti individu, organisasi, masyarakat, dan sebagainya diadakan melalui suatu cara yang sistematis seperti pengisian daftar pertanyaan, wawancara dan lain sebagainya. Sampel dalam penelitian ini adalah perusahaan manufaktur skala menengah dan perusahaan besar di wilayah Kota Palembang yang ditujukan kepada manajer fungsional atau kepala bagian setingkat manajer pada perusahaan tersebut. Dalam penelitian ini menggunakan 100 sampel. Dilakukan analisis regresi untuk mengestimasi koefisien path $(\rho)$. Dalam analisis ini, hubungan antar variabel ditentukan dengan serangkaian koefisien path yang koefisiennya ekuivalen dengan standarisasi koefisien beta yang diperoleh dari persamaan regresi yang hasilnya juga sama denga koefisien korelasi dari dua variabel yang diukur. Untuk mengetahui keeratan hubungan antar variabel di dalam analisis jalur ini digunakan analisis korelasi.

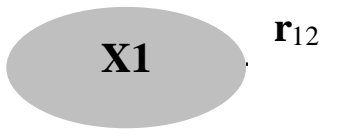

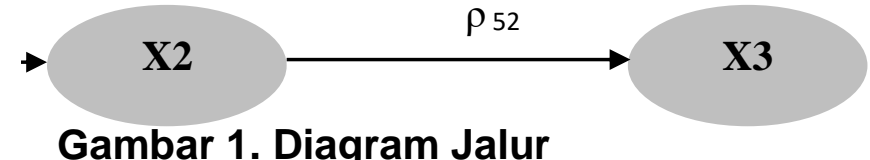

Gambar 1. Diagram Jalur

\section{PEMBAHASAN}

Untuk mengetahui hasil uji hipotesis variabel yang diteliti harus distandarisasi dahulu, buatkan diagram jalur yang menggambarkan pola hubungan atau pengaruh antar variabel yang diteliti dalam kerangka kerja teoritis, dan dihitung dengan menggunakan analisis regresi untuk mengestimasi koefisien path yang nilainya ekuivalen dengan hasil perhitungan korelasi. Hasil yang dapat diamati dari perhitungan analisis korelasi antar variabel yang diteliti yang nilainya ekuivalen dengan standarisasi koefisien beta dari analisis regresi dapat dilihat dari tabel 1 berikut ini.

Tabel 1.

Hasil Uji Regresi Linear

\begin{tabular}{|l|c|c|c|c|}
\hline Pengaruh Antar variabel & $\boldsymbol{\beta}$ & Sig & Nilai t & Nilai F \\
\hline Self Efficacy & 0,258 & 0,023 & 2,284 & 17,522 \\
\hline
\end{tabular}

Sumber : pengolahan data primer

Dari hasil olah data yang tersaji dalam tabel 1, dapat diketahui bahwa nilai koefisien regresi dari partisipasi anggaran ( X1) adalah sebesar 0,152, tingkat probabilitasnya sebesar 0,029 . Hipotesis pertama ( $\mathrm{H} 1$ ) akan diterima jika hitung tabel thitung $>t_{\text {tabel }}$, dan nilai probabilitasnya di bawah 0,05 . Hasil olah data dalam penelitian ini menunjukkan bahwa nilai hitung tabel $t_{\text {thitung }}>t_{\text {tabel }}(2,284>1,652)$, dan probabilitasnya di bawah 0,05 , sehingga hipotesis pertama diterima karena memenuhi syarat yang telah ditentukan atau dapat diartikan terdapat pengaruh yang signifikan dari variabel partisipasi anggaran terhadap self efficacy. Hipotesis ini sesuai dengan yang diajukan oleh penulis sebelumnya.

Hasil uji regresi dari variabel self efficacy dengan kinerja manajerial menunjukkan nilai koefisien regresi sebesar 0,258 , tingkat probabilitasnya adalah 0,023, dan nilai hitung $t$ sebesar 2,284. Hipotesis akan diterima jika hitung tabel thitung $>t_{\text {tabel }}$ dan nilai probabilitasnya di bawah 0,05 . Hasil olah data dalam penelitian ini menunjukkan bahwa hitung tabel thitung $>$ tabel $(2,284>1,652)$ dan nilai probabilitasnya berada di bawah 0,05. 
Hal ini berarti terdapat pengaruh yang positif dan signifikan antara variabel self efficacy dengan kinerja manajerial.

\section{E. PENUTUP}

1. Berdasarkan fakta empiris dari uji hipotesis pertama dalam penelitian ini dapat ditarik kesimpulan bahwa terdapat pengaruh yang positif dan signifikan antara partisipasi anggaran dengan variabel self efficacy.

2. Berdasarkan fakta empiris dari uji hipotesis ketujuh dalam penelitian ini dapat ditarik kesimpulan bahwa terdapat pengaruh yang positif dan signifikan antara self efficacy dengan kinerja manajerial.

3. Berdasarkan fakta empiris dari uji hipotesis kdalam penelitian ini dapat ditarik kesimpulan bahwa dengan menggunakan variabel intervening akan memiliki pengaruh lebih besar daripada dengan menggunakan pengaruh secara langsung. Pengaruh secara langsung menunjukkan angka sebesar 0,176 sedangkan dengan menggunakan intervening diperoleh angka sebesar 0,265.

\section{DAFTAR PUSTAKA}

Arfan Ikhsan Lubis. 2011. Akuntansi Keperilakuan Edisi 2. Jakarta: Salemba Empat.

Arfan Ikhsan dan Muhammad Ishak. 2008. Akuntansi Keperilakuan. Jakarta: Salemba Empat.

Eka Yudha Utama. 2013. Pengaruh Partisipasi Penyusunan Anggaran Terhadap Kinerja Manajerial: Komitmen Organisasi dan Persepsi Inovasi Sebagai
Variabel Intervening (Studi Empiris Pada Satuan Kerja Instansi Vertikal Wilayah Pembayaran Kantor Pelayanan Perbendaharaan Negara Sampit). Skripsi. Universitas Diponegoro.

Gibson. 2006. Perilaku Organisasi. Buku 1. Edisi Kedua Belas. Jakarta, Indonesia: Salemba Empat

Hasibuan, SP Malayu. 2017. Manajemen Sumber Daya Manusia (Edisi Revisi). Jakarta, Indonesia: Bumi Aksara.

Indra Bastian. 2006. Akuntansi Sektor Publik: Suatu Pengantar. Jakarta: Erlangga.

Mardiasmo. 2009. Akuntansi Sektor Publik. 2 ed. Yogyakarta: Andy

Nurcahyani,K. 2010. "Pengaruh Partisipasi Anggaran Terhadap Kinerja Manajerial Melalui Komitmen Organisasi dan Persepsi Inovasi Sebagai Variabel Intervening". Skripsi Tidak Dipublikasikan, Fakultas Ekonomi, Universitas Diponegoro

Ramadhani dan Nasution. 2009. Pengaruh Partisipasi Anggaran Terhadap Prestasi Manajer Pusat Pertanggungjawaban dengan Motivasi Sebagai Variabel Mediating. Jurnal tidak dipublikasikan. Faculty of Economic, University of Sumatera Utara

$\begin{array}{cr}\text { Suparmoko dan } & \text { Sofilda, } \\ \text { Eleonora.(2015). } & \text { Pengantar } \\ \text { Ekonomi } & \text { Makro } \\ \text { 5.Jakarta:IN-MEDIA } & \text { Edisi } \\ & \end{array}$

